\title{
Numerical simulation of the performance of proton exchange membrane fuel cell with different membrane geometries
}

\author{
Mohammed Jourdani *, Hamid Mounir and Abdellatif EL Marjani \\ EMISys Research Team, Engineering 3S Research Center \\ Mohammadia School of Engineers Mohammed V University \\ Rabat, Morocco \\ *Email: jourdani.mohammed@gmail.com \\ Phone: +212 6710935 80; Fax: +212537 778853
}

\begin{abstract}
The performance of proton exchange membrane fuel cell (PEMFC) under different membrane geometries is investigated using a three-dimensional mathematical model. The proton exchange membrane fuel cell is mainly composed of bipolar plates, a gas diffusion layer, a micro porous layer, a catalyst layer, and a membrane. The numerical model is simulated in the comsol multiphysics to study the effects of different membrane geometries on the performance of the proton exchange membrane fuel cell. The results show that the performance of the proton exchange membrane fuel cell improves as the membrane's thickness is scaled down towards being nanoscale. The model was compared with experimental trends and there is a good agreement between experimental data trends and the proposed model.
\end{abstract}

Keywords: Performance; Simulation; Membrane; Performance; geometry; Mathematical model.

\section{INTRODUCTION}

A fuel cell is an electrochemical device [1-3] which directly converts chemical energy to electrical energy. It has a lot of advantages such as high power, safe construction, and simple and fast start-up, making it particularly suitable for home appliances, vehicles and transportation tools [4]. Within the few years [5, 6], so many progresses have been made for PEMFCs in terms of design, material, manufacturing and applications. Until this moment, cost is thought to be one of the major problems behind the commercialization of PEMFCs in addition to its performance, durability and hydrogen storage. It is known that the performance of the proton exchange membrane fuel cell (PEMFC) is highly influenced by its geometry, material and operating parameters [720]. So many parameter conditions are used in running the PEMFC such as temperature, design, pressure, etc., and these are the key factors which greatly affect the PEMFC's performance. Membrane is the most important component of PEMFC [21]. It is a proton conductor between two electrodes, the anode and cathode, and at same time it pushes electrons to flow through an external circuit in order to produce useful electricity. It also acts as a physical barrier between the anode and the cathode by stopping the penetration of fuel from the cathode side to the anode side or vice versa. According to our previous study on the factors affecting the durability and performance of PEMFC, we concluded that the performance of the PEM fuel cell depends strongly on the performance of its 
membrane. Figure 1 presents all the factors affecting the performance of the membrane. It seems that the membrane is highly influenced by its conductivity. So, we can understand that the thickness of the membrane is related to its conductivity [22-26]. In fact, when we increase the membrane's thickness, the conductivity is decreased. The thickness of the membrane is among the key factors that increase the performance of a polymer electrolyte membrane fuel cell. In literature, several modelling and experimental studies have been conducted in order to understand the effect of membrane thickness on fuel cell performance. Atifi et al. [27] presented the effect of internal current, fuel crossover, and membrane thickness on PEMFC performance. The results obtained show that internal current and fuel crossover can be reduced by using a thicker membrane and that the activation over potential increases as temperature increases. Ionescu et al. [28] presented a two-dimensional model for PEMFC with different width dimensions of the PEM membrane: $50 \mu \mathrm{m}, 100 \mu \mathrm{m}$ and $200 \mu \mathrm{m}$. The $50 \mu \mathrm{m}$ cell model showed the smallest ohmic losses by registering the smallest voltage drop (of $6.9 \mathrm{mV}$ ) across the electrolyte membrane and also the smallest over potential drop along the cell length. But there is no validation using experimental study.

Belkhiri et al. [29] presented a two-dimensional model which analyses the effect of temperature and water content on the proton conductivity of the membrane, and he concluded that the electrochemical performance of a fuel cell strongly depends on the temperature and water content. The conductivity of the membrane $\left(\sigma_{\mathrm{m}}\right)$ increases with increase in temperature, and leads to greater diffusion of hydrogen protons within the membrane. Thus, with resistance of the membrane which means higher temperatures, the electrochemical reaction is faster, thus increasing the production of water in the cathode and better hydration of the membrane, thus ionic resistance is reduced. A few studies not only include the thickness of membrane, but they also include other parameters [30], thus not allowing us to understand 100\% the effect of the thickness of the membrane on the performance of PEMFC. Furthermore, other studies did not validate their findings using experimental work. In these cases, we cannot know the exactitude of the results. In this paper, our work focuses only on the geometry of the membrane by supposing that other parameters are kept constant. A 3D mathematical model is used to simulate the model with different membrane geometries; the results are compared with the experimental study of A. Martin and Bates [31]. The purpose of our study is to investigate the performance of PEMFC under different membrane thicknesses. The results of this work show the performance of PEMFC at different membrane thicknesses, and that it may be of interest to engineers attempting to develop the optimization of a PEMFC and to researchers who are interested in the flow modification aspects of a PEMFC's performance enhancement.

\section{METHODS AND MATERIALS}

\section{Mathematical Modelling}

Figure 1 illustrates a 3-dimensional model of a single channel PEMFC. The model is composed of seven zones which are the anode channel, anode GDL, anode electrode, membrane, cathode electrode, cathode GDL, and cathode channel. The geometry parameters of the model are listed in Table 1 and are taken from the experimental study published by Alex Martin et al [31]. For our model, the following assumptions were employed:

3D domain; Cell temperature is held constant; Laminar flow due to small pressure gradients and Reynolds number $(\operatorname{Re}<1)$; Stationary model; The membrane is 
impermeable to gas; Membrane and electrodes are isotropic and homogeneous; The GDL is porous; Ideal gas; The fluid is incompressible.

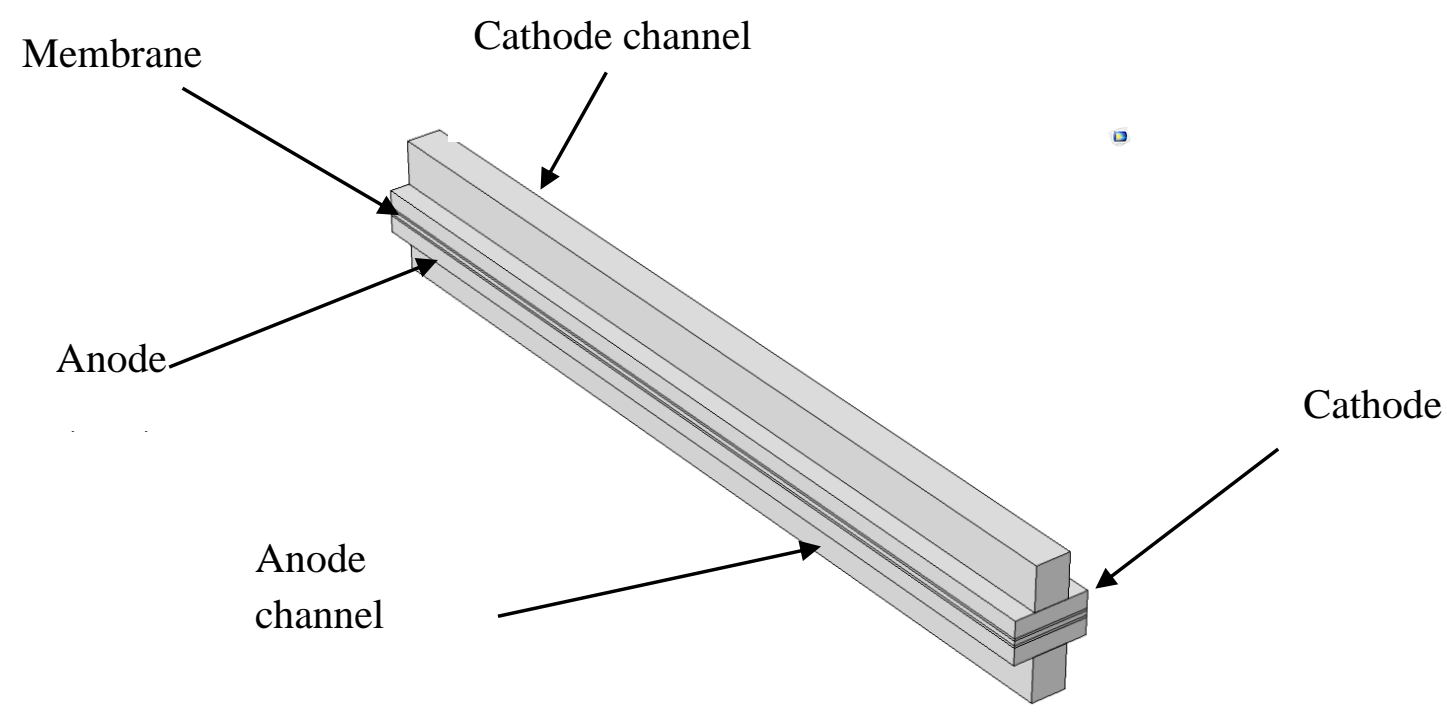

Figure 1. Geometry model.

Table 1. Design parameters.

\begin{tabular}{ll}
\hline Description & Value \\
\hline Cell length L & $0.01 \mathrm{~m}$ \\
Channel height H_ch & $1.1 \mathrm{e}^{-3} \mathrm{~m}$ \\
Channel width W_ch & $1.1 \mathrm{e}^{-3} \mathrm{~m}$ \\
Rib width Wrib & $0.90932 \mathrm{e}^{-3} \mathrm{~m}$ \\
GDL width H_gdl & $380 \mathrm{e}^{-6} \mathrm{~m}$ \\
Electrode thickness Hel & $50 \mathrm{e}^{-6} \mathrm{~m}$ \\
Membrane thickness Hm & $100 \mathrm{e}^{-6} \mathrm{~m}$ \\
\hline
\end{tabular}

\section{Governing Equations}

The form of mathematical equations for continuity, momentum, energy, species and charge can be summarized as follows [32]:

\section{Continuity equation}

\section{Momentum Conservation}

$$
\frac{\partial(\varepsilon \rho)}{\partial t}+\nabla \cdot(\varepsilon \rho U)=0
$$

$$
\frac{\partial(\varepsilon \rho U)}{\partial t}+\nabla \cdot(\varepsilon \rho U U)=-\varepsilon \nabla p+\varepsilon F+\nabla \cdot(\varepsilon \tau)-\frac{\varepsilon^{2} \mu}{k} U
$$

where for Eqs. (1) and (2)

$\varepsilon$ is the porosity for a porous medium; $\rho$ is the density of the liquid; $U$ is the floating speed vector when the liquid in the porous medium; $p$ is the pressure; $F$ is the floating mass vector; $\tau$ is the stress tensor; $\mu$ is the liquid viscidity degree, and $k$ is the permeate ratio of the liquid through the porous medium. 


\section{Conversation of energy equation}

$$
\nabla \cdot\left(\rho U C_{p} T\right)=\nabla \cdot\left(K^{e f f} \nabla T\right)+S_{T}
$$

where $C_{p}$ is represents the specific heat capacity at constant pressure; $\mathrm{K}^{\mathrm{eff}}$ is the effective thermal conductivity of gas mixture in porous medium, and $S_{\mathrm{T}}$ is energy source term which represents the rate of increase or decrease of energy due to heat generations or consumptions.

\section{Conservation of species equation}

$$
\frac{\partial\left(\varepsilon \rho X_{i}\right)}{\partial t}+\nabla \cdot\left(\varepsilon \rho U X_{i}\right)=\nabla \cdot N_{i}+S_{i}
$$

where $X_{i}$ is the mass fraction of species $i$, and $S_{i}$ is the produced speed of species $i$ adapted to the electrochemistry reaction.

According to Fick's law, the mass diffusion flux of the species i in a porous medium is:

$$
N_{i}=-\rho D_{i} X_{i}
$$

where $D_{i}$ is the gas diffusion coefficient in nonporous material and can be calculated from the binary diffusion coefficient.

\section{Membrane}

Water management is a critical issue for the performance of a proton electrolyte membrane fuel cell. The transport phenomena of water can be described as follows: water molecules are transported through a polymer electrolyte membrane by hydrogen protons, and this process is called electro-osmotic drag. In addition to the molecular diffusion and electro-osmotic drag, water is generated in the cathode catalyst layer due to electrochemical reaction.

Electro-osmotic water flux through the membrane can be calculated from the proton flux through the membrane, as given by specified current density and Faraday law;

$$
J_{H_{2} \mathrm{O}}=2 \times n_{d} \frac{I(x, x)}{2 F} \text { : Electro-osmotic drag flux }
$$

where $n_{d}$ is the electro-osmotic drag coefficient which depends on water activity as follows;

$$
n_{d}=0.0029 \lambda^{2}+0.05 \lambda-3.4 \times 10^{-19}
$$

where $\lambda$ represents the water content of the membrane, which is described as;

$$
\begin{aligned}
& \lambda=0.043+17.81 a_{k}-39.85 a^{2}{ }_{k}+36.0 a^{3}{ }_{k}, 0 \prec a_{k} \prec 1 ; \\
& \lambda=14+1.4\left(a_{k}-1\right), 1 \prec a_{k} \prec 3 ;
\end{aligned}
$$

where $a_{K}$, is water activity, which is expressed as; 


$$
a_{k}=\frac{X_{w, K} P(x, y)}{P^{s a t}{ }_{w, K}}, \mathrm{~K}=\text { Anode or cathode }
$$

where $\mathrm{X}, \mathrm{K}$, and Psat are the water mole fraction and saturation pressures at each electrode, respectively.

$$
\log _{10} P^{\text {sat }}=-2.1794+0.02953 T-9.1837 \times 10^{-5} T^{2}+1.4454 \times 10^{-7} T^{3}
$$

\section{Electrochemical Model}

The electrochemical model of a single cell of the proton exchange membrane fuel cell is modelled by the following equations [33]:

$$
V_{\text {cell }}=E-V_{\text {activation }}-V_{\text {ahmic }}-V_{\text {concentration }}
$$

where $\mathrm{V}_{\text {cell }}$ Fuel cell voltage

- E : Reversible voltage

- $\mathrm{V}_{\text {activation: Activation voltage }}$

- $\mathrm{V}_{\text {ohmic: }}$ Ohmic voltage

- $\mathrm{V}_{\text {concentration: Concentration voltage }}$

$$
E=\frac{\Delta G}{2 F}+\frac{\Delta S}{2 F}\left(T-T_{r e f}\right)+\frac{R T}{2 F}\left[\ln \left(P_{H_{2}}\right)+\frac{1}{2} \ln \left(P_{O_{2}}\right)\right]
$$

Using the standard pressure and temperature values for $\Delta \mathrm{G}, \Delta \mathrm{S}$ and $\mathrm{T}_{r e f}$, Eq. (7) can be simplified to [34]:

$$
\begin{gathered}
E=1.229-0.85 \times 10^{-3}(T-298.15)+4.31 \times 10^{-5} T\left[\ln \left(P_{H_{2}}\right)+\frac{1}{2} \ln \left(P_{O_{2}}\right)\right] \\
V_{\text {activation }}=\frac{R T}{2 \Omega T} \ln \left(\frac{i}{i_{0}}\right) \\
V_{\text {ohmic }}=i\left(r_{\text {ion }}+r_{\text {el }}\right) \\
V_{\text {con }}=-b \cdot \ln \left(1-\frac{j}{j_{\text {max }}}\right)
\end{gathered}
$$

where in Eqs. (12)-(16), $\Delta \mathrm{G}$ is the change in the Gibbs free energy; $F$ is the constant of Faraday; $\Delta S$ is the change of the entropy; $R$ is the universal constant of the gases; $P_{H 2}$ and $P_{O 2}$ are the partial pressures of hydrogen and oxygen; $T$ is the cell operation temperature; Tref is the reference temperature; $\Omega$ is electron transfer coefficient; $i$ is the cell's current density; $i_{0}$ is exchange current density; $b$ is a parametric coefficient; and $J$ represents the actual current density of the cell $\left(\mathrm{A} / \mathrm{cm}^{2}\right)$ 


\section{Boundary conditions}

The boundary conditions and inlet parameters for the numerical model are summarized in Table 2.

Table 2. Boundary conditions.

\begin{tabular}{|c|c|c|c|c|c|}
\hline Domain & $\begin{array}{c}\text { Temp. } \\
\mathrm{T}\end{array}$ & $\begin{array}{c}\text { Mass flow } \\
{[\mathrm{kg} / \mathrm{mol}]}\end{array}$ & $\begin{array}{l}\text { Electric potential } \\
(\mathrm{V})\end{array}$ & & \\
\hline $\begin{array}{l}\text { Inlet-a } \\
\text { (anode) }\end{array}$ & 333 & 0.002 & - & $\begin{array}{l}\mathrm{O} 2 \text { mass fraction } \\
\mathrm{H} 2 \text { mass fraction } \\
\mathrm{H} 20 \text { mass fraction }\end{array}$ & $\begin{array}{c}0 \% \\
0.743 \% \\
0 \%\end{array}$ \\
\hline $\begin{array}{c}\text { Inlet-c } \\
\text { (Cathode) }\end{array}$ & 333 & 0.032 & - & $\begin{array}{l}\mathrm{O} 2 \text { mass fraction } \\
\mathrm{H} 2 \text { mass fraction } \\
\mathrm{H} 20 \text { mass fraction }\end{array}$ & $\begin{array}{c}0.228 \% \\
0 \% \\
0.023 \%\end{array}$ \\
\hline Outlet-a & 333 & - & - & - & - \\
\hline Outlet-c & 333 & - & - & - & - \\
\hline Terminal-a & 353 & - & 0 & - & - \\
\hline Terminal-c & 333 & - & 0.75 & - & - \\
\hline
\end{tabular}

\section{Numerical Procedure}

The model geometry is meshed with a structured grid (Figure 2) by the Comsol 5.0. The complete mesh consisted of 6880 domain elements, 3516 boundary elements and 628 edge elements. The governing equations were solved using Comsol boundary conditions with a simple algorithm based on the finite element technique. The calculations took $51 \mathrm{~min} 47 \mathrm{~s}$ in order to show the study diagrams. The model operated at a constant temperature of $333 \mathrm{~K}$ at a reference pressure of $101 \mathrm{e}^{3}(\mathrm{~Pa})$. The geometry of the cell model is listed in Table 1 . The physicochemical parameters' values that were used in this model are listed in Table 3.

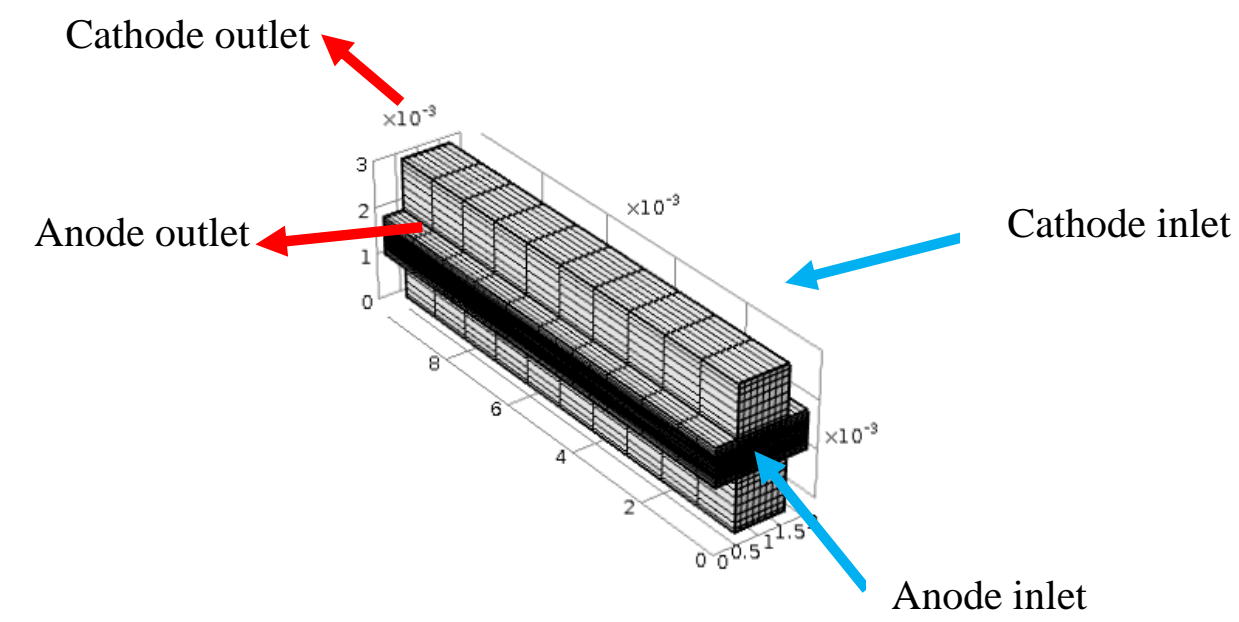

Figure 2. Structure after meshing. 
Table 3. Operating parameters

\begin{tabular}{|c|c|}
\hline Parameter & Value \\
\hline GDL porosity & 0.4 \\
\hline GDL permeability $\left(\mathrm{e}^{-11} \mathrm{~m}^{2}\right)$ & 1.18 \\
\hline GDL electric conductivity ( $\mathrm{S} / \mathrm{m})$ & 222 \\
\hline Inlet $\mathrm{H} 2$ mass fraction (anode) & 0.743 \\
\hline Inlet $\mathrm{H} 2 \mathrm{O}$ mass fraction (cathode) & 0.023 \\
\hline Inlet oxygen mass fraction (cathode) & 0.228 \\
\hline Anode inlet flow velocity $\mathrm{m} / \mathrm{s}$ & 0.4 \\
\hline Cathode inlet flow velocity $\mathrm{m} / \mathrm{s}$ & 0.7 \\
\hline Anode viscosity ( $\mathrm{e}^{-5}$ Pa.s) & 1.19 \\
\hline Cathode viscosity ( $\mathrm{e}^{-5}$ Pa.s) & 2.46 \\
\hline Hydrogen molar mass ( $\mathrm{kg} / \mathrm{mol})$ & 0.002 \\
\hline Nitrogen molar mass $(\mathrm{kg} / \mathrm{mol})$ & 0.028 \\
\hline Water molar mass $(\mathrm{kg} / \mathrm{mol})$ & 0.018 \\
\hline Oxygen molar mass $(\mathrm{kg} / \mathrm{mol})$ & 0.032 \\
\hline $\mathrm{H} 2-\mathrm{H} 2 \mathrm{O}$ Binary diffusion coefficient $\left(\mathrm{e}^{-4} \mathrm{~m}^{2} / \mathrm{s}\right)$ & 1.55 \\
\hline $\mathrm{N} 2-\mathrm{H} 2 \mathrm{O}$ Binary diffusion coefficient $\left(\mathrm{e}^{-5} \mathrm{~m}^{2} / \mathrm{s}\right)$ & 2.95 \\
\hline $\mathrm{O} 2-\mathrm{N} 2$ binary diffusion coefficient $\left(\mathrm{e}^{-5} \mathrm{~m}^{2} / \mathrm{s}\right)$ & 2.75 \\
\hline $\mathrm{O} 2-\mathrm{H} 2 \mathrm{O}$ binary diffusion coefficient $\left(\mathrm{e}^{-5} \mathrm{~m}^{2} / \mathrm{s}\right)$ & 3.23 \\
\hline Cell temperature $(\mathrm{K})$ & 333 \\
\hline Reference pressure $(\mathrm{Pa})$ & $101 \mathrm{e}^{3}$ \\
\hline Cell voltage $\mathrm{V}$ & 0.9 \\
\hline Oxygen reference concentration $(\mathrm{mol} / \mathrm{m}$ & 40.88 \\
\hline Hydrogen reference concentration (mol/m3) & 40.88 \\
\hline Membrane conductivity (S/m) & 9.82 \\
\hline
\end{tabular}

\section{RESULTS AND DISCUSSION}

\section{Model Validation}

In order to validate our model, the numerical study obtained from the present model is compared with an experimental study conducted by Martin Bates [31] (Figure 3). In the activation and ohmic area of the polarization curve, our results using Comsol are a good match with the compared experimental study with only a deviation at $0.5 \mathrm{~A} / \mathrm{cm}^{2}$ (Figure 4). As we can see that the model was unable to reproduce the experimental data at high current densities. This may be caused by the presence of liquid water in the catalyst layers and the gas diffusion layers.

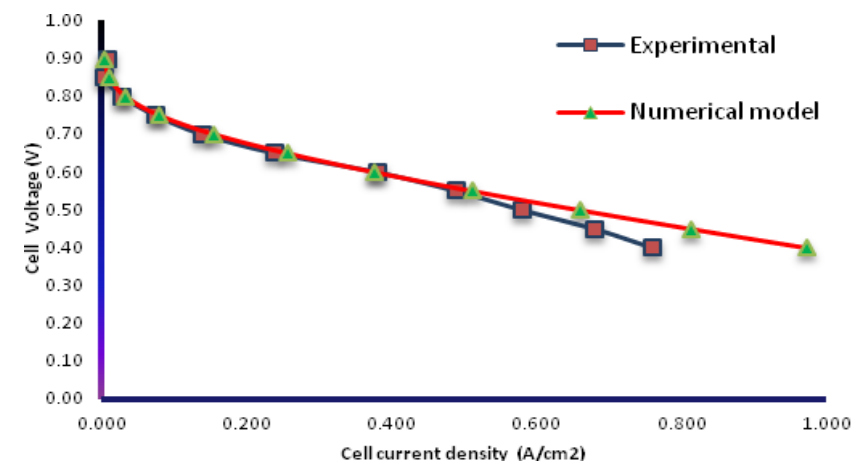

Figure 3. Comparison between experimental data and the current modelling results. 


\section{Optimization of Cell Performance}

Based on the results above, it is now possible to consider a reference case and investigate its performance behaviour under different membrane thicknesses. The cell geometry and flow conditions for the reference case are listed in Tables 1 and 2 . Figure 4 shows the overall full cell performance in terms of polarization obtained under the four operating membrane thicknesses. According to the comparison, we can see that the PEMFC has the highest cell potential at $50 \mathrm{e}^{-6} \mathrm{~m}$, especially in the high current density region. A low ohmic loss and a high concentration loss were observed at $125 \mathrm{e}^{-}$ ${ }^{6} \mathrm{~m}$. Ohmic loss was found to increase with temperature and the loss was significant for higher temperatures. The modelling results will be used to explore the transport phenomena inside the fuel cell and the effects of the membrane on fuel cell performance. All of the following results are generated at a constant cell voltage of $0.9 \mathrm{~V}$.

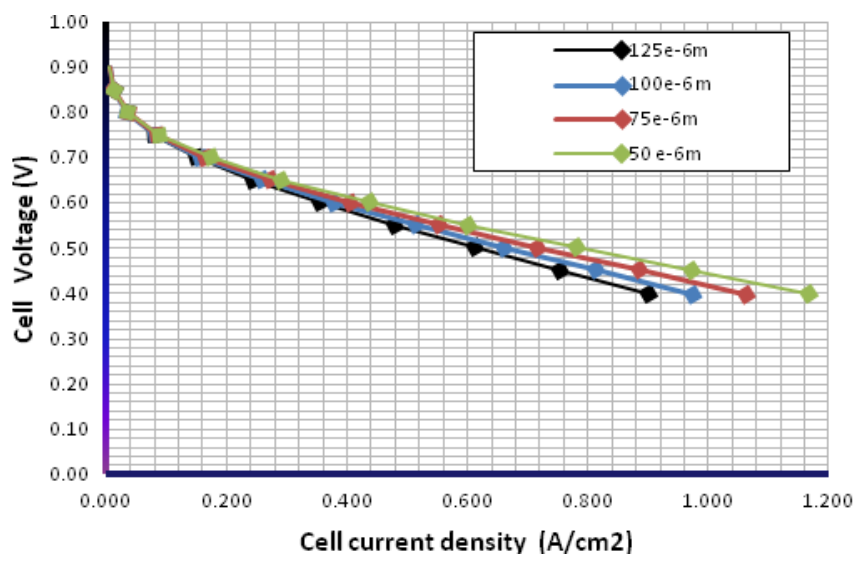

Figure 4. Comparison of polarization curves by PEMFC at different membrane thicknesses.

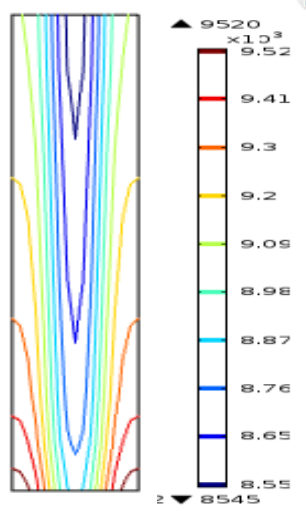

$125 \mathrm{e}-6 \mathrm{~m}$

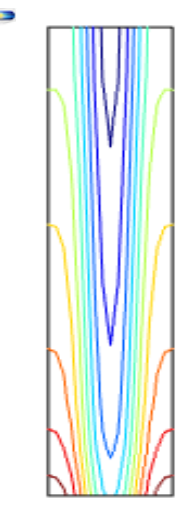

$100 \mathrm{e}-6 \mathrm{~m}$
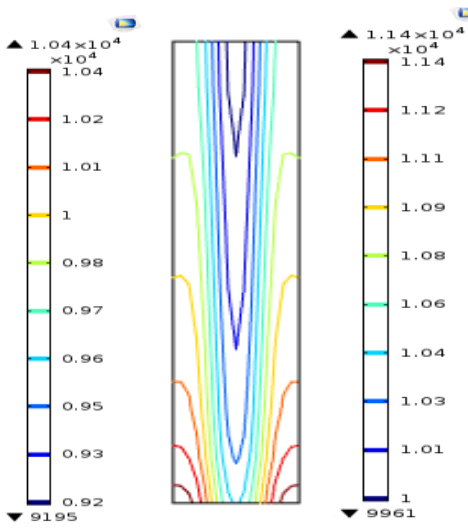

$75 \mathrm{e}^{-6} \mathrm{~m}$

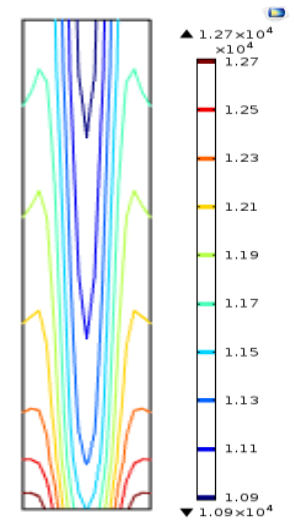

$50 \mathrm{e}^{-6} \mathrm{~m}$

Figure 5. Current density in membrane under four thicknesses.

Figure 5 shows the current densities using four membrane thicknesses at the centre of the membrane for $0.9 \mathrm{~V}$. We can see that the current density is lower towards the outlet of cell due to lower reactant concentrations. As we can also see, the current density is highest in the region closer to the channel where the reactant concentrations 
are higher, but the current density is lower in the centre of the channel. This is due to the ohmic drops in the GDLs. According to this comparison, we can see that the thickness of $50 \mathrm{e}^{-6} \mathrm{~m}$ is the best operating thickness among the four thickness measurements for this fuel cell under the specified operating conditions.

Figures 6 and 7 show that the largest water concentration was in the cell at A $\left(50 \mathrm{e}^{-6} \mathrm{~m}\right)$ for the same voltage level. In order to increase to the conductivity of the membrane, the temperature of the cell must be increased. In fact, large membrane thicknesses will result in late conductivity, so the optimal membrane thickness is needed for faster electrochemical reaction. This means that the production of water must be increased to hydrate the membrane better, thus ionic resistance can be reduced.

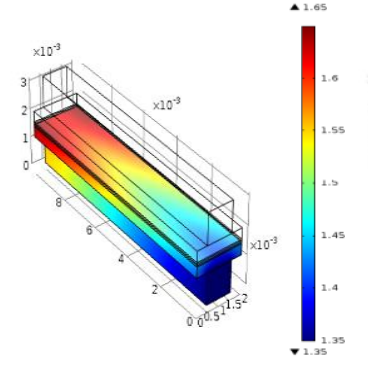

A $\left(50 \mathrm{e}^{-6} \mathrm{~m}\right)$

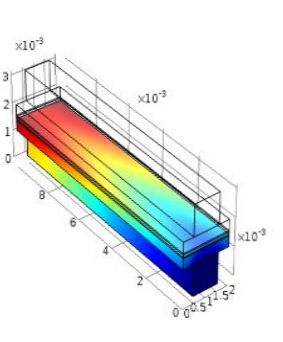

B $\left(75 \mathrm{e}^{-6} \mathrm{~m}\right)$
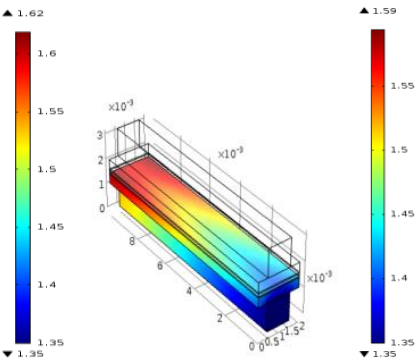

C $\left(100 \mathrm{e}^{-6} \mathrm{~m}\right)$

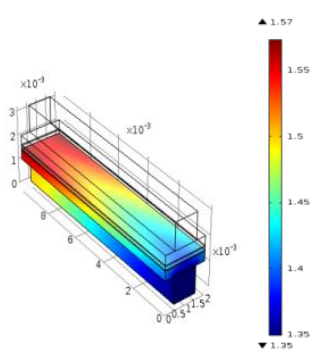

$\mathrm{D}\left(125 \mathrm{e}^{-6} \mathrm{~m}\right)$

Figure 6. Anode water concentrations at different membrane thicknesses A, B, C, D

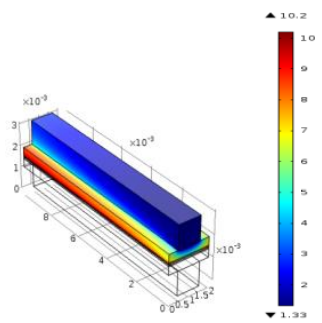

A $\left(50 \mathrm{e}^{-6} \mathrm{~m}\right)$

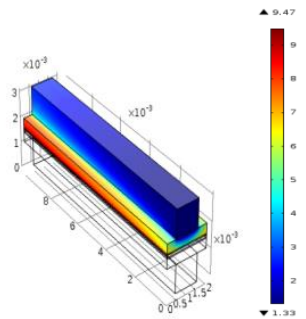

B $\left(75 \mathrm{e}^{-6} \mathrm{~m}\right)$

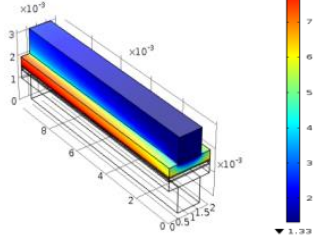

C $\left(100 \mathrm{e}^{-6} \mathrm{~m}\right)$

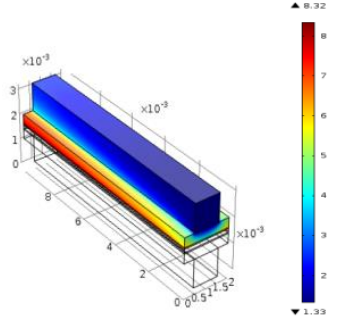

$\mathrm{D}\left(125 \mathrm{e}^{-6} \mathrm{~m}\right)$

Figure 7. Cathode water concentrations at different membrane thicknesses A, B, C, D

\section{CONCLUSIONS}

The performance of the PEMFC is affected by the resistance of proton transport across the membrane, which depends on the geometry of the membrane. The potential loss in the cell is due to the resistance to proton transport across the membrane from the anode to the cathode. Thus, a thinner membrane means that the path travelled by the protons will be decreased; thereby reducing membrane resistance, and leading to the reduction in the potential loss of the membrane. This study found that reducing the membrane thickness plays a significant role in promoting cell performance.

\section{ACKNOWLEDGEMENTS}

The author would like to express gratitude to Mohammadia School of Engineers and Mohammed V University Rabat for supporting these research activities. 


\section{REFERENCES}

[1] Jourdani M, Mounir H, El Marjani A. Compilation of factors affecting durability of proton exchange membrane fuel cell (PEMFC). International Journal of Engineering Science and Advanced Technology2014;7:100-7.

[2] Mustafa MYFA. Design and manufacturing of a (PEMFC) proton exchange membrane fuel cell. retrive from https://core.ac.uk/download/pdf/30617737.pdf; dated on 2017.

[3] Viswanathan B, Scibioh MA. Fuel cells Principles and applications. Chennai: University Press , 2006.

[4] Ho W. Applications of proton exchange membrane fuel cell systems. Renewable and Sustainable Energy Reviews. 2007; 11(8):1720-38.

[5] Fuel Cell Industry Review. 2015, E4tech strategic thinking in sustainable energy.p.16-35.

[6] Fuel Cells Section, Multi-Year Research, Development, and Demonstration Plan; 2016.

[7] Maslan NH, Gau MM, Masdar MS, Rosli MI. Simulation of porosity and PTFE content in gas diffusion layer on proton exchange membrane fuel cell performance. Journal of Engineering Science and Technology. 2016;11:85-95.

[8] Rameshkumar K, Girimurugan R, Jegan M. Numerical Investigation of Reactant Gases Pressure Distribution at Gas Diffusion Layer in High Temperature PEM Fuel Cell with Single Flow Channel Configuration. International Journal of Research. 2015;2:303-8.

[9] Youcef K, Yasmina KZ, Ahmed B. Modeling of transport phenomena in a PEM fuel cell. International Journal of Soft Computing and Engineering. 2013;3(1):334-6.

[10] Efunda. [cited 18.05.09]; Available from: http://www.efunda.com/glossary/ units/units--electric_conductivity-siemens_per_centimeter.cfm.

[11] Savadogo O. Emerging membranes for electrochemical systems: Part II. High temperature composite membranes for polymer electrolyte fuel cell (PEFC) applications. Journal of Power Sources. 2004;127:135-61.

[12] Haile SM. Fuel cell materials and components. Acta Materialia 2003.51:59816000.

[13] Cooper JS. Design analysis of PEMFC bipolar plates considering stack manufacturing and environment impact. Journal of Power Sources 2004.129:152-69.

[14] Paul TY, Gu W, Makharia R, Wagner FT, Gasteiger HA. The impact of carbon stability on PEM fuel cell startup and shutdown voltage degradation. 210th ECS Meeting, Cancun, Mexico, Durability-Fuel Starvation and Start/Stop Degradation; 2006.

[15] Larminie J, Dicks A, McDonald MS. Fuel Cell Systems Explained. Chichester: Second Edition. John Wiley \& Sons. 2003.

[16] Yan WM, Hsueh CY, Soong CY, Chen F, Cheng CH, Mei SC. Effects of fabrication processes and material parameters of GDL on cell performance of PEM fuel cell. International Journal of Hydrogen Energy. 2007;32:4452-8.

[17] Zakaria I, Michael Z, Mohamed WANW, Mamat AMI, Azmi WH, Mamat R, et al. A review of nanofluid adoption in polymer electrolyte membrane (PEM) fuel cells as an alternative coolant. Journal of Mechanical Engineering and Sciences. 2015;8:1351-66. 
[18] Omar SMHS, Arshad NM, Yassin IM, Fakharuzi MHAM, Ward TA. Design and optimization of powertrain system for prototype fuel cell electric vehicle. Journal of Mechanical Engineering and Sciences. 2015;8:1401-13.

[19] Mohd Fakharuzi MHA, Abdol Rahim AH, Tijani AS, Sainan KI, Wan Mohamed WAN. Effect of gear ratio on the DC motor efficiency of a mini-fuelcell vehicle cruising at constant speeds. Journal of Mechanical Engineering and Sciences. 2015;8:1460-71.

[20] Mohamed WANW, Atan R. Polymer electrolyte membrane fuel cell. International Journal of Automotive and Mechanical Engineering. 2012;5:64859.

[21] Al-Baghdadi MAS. "Mechanical behaviour of membrane electrode assembly (MEA) during cold start of PEM fuel cell from subzeroenvironment temperature,". International Journal of Energy and Environment. 2015;6:107-14.

[22] Broka K, Ekdunge P. Oxygen and hydrogen permeation properties and water uptake of Nafion 117 membrane and recast film for PEM fuel cell. Sweden, Chapman \& Hall; 1997.

[23] Ceraolo M, Miulli C, Pozio A. Modelling Static and dynamic behavior of proton exchange membrane fuel cells on the basis of electro-chemical description. Journal of Power Sources. 2003;113:131-44.

[24] Janssen G, Overvelde M. Water transport in the proton-exchange-membrane fuel cell: Measurements of the effective drag coefficient. Journal of Power Sources. 2001;101:117-25.

[25] Morris DR, Sun X. Water-sorption and transport properties of Nafion $117 \mathrm{H}$. Journal of Applied Polymer Science. 1993;50:1445-52.

[26] Chen D, Peng H. Modeling and simulation of a PEM fuel cell humidification system. Proceeding of the American Control Conference Boston; 2004.

[27] Atifi A, Mounir H, El Marjani A. Effect of internal current, fuel crossover, and membrane thickness on a PEMFC performance. Proceedings of International Renewable and Sustainable Energy Conference; 2014. p. 907-12.

[28] Ionescu V. Finite element method modelling of a high temperature pem fuel cell. Romanian Journal of Physics 2014;59(3):285-94.

[29] Belkhiri Z, Zeroual M, Moussa HB, Zitouni B. Effect of temperature and water content on the performance of PEM fuel cell. Revue des Energies Renouvelables 2011;14(1):121-30.

[30] Khazaee I, Ghazikhani M, Esfahani MN. Effect of gas diffusion layer and membrane properties in an annular proton exchange membrane fuel cell. Applied Surface Science. 2012;258:2141-8.

[31] Bates AM. Experimental and analytical study of an open cathode polymer electrolyte membrane fuel cell. Electronic Theses and Dissertations; 2015.

[32] Wei Y, Zhu H. Model and simulation of proton exchange membrane fuel cell performamnce at different porosity of diffusion layer. International Journal of Modern Education and Computer Science. 2011;2:22.-8

[33] Beicha A, Zaamouche R. Electrochemical model for proton exchange membrane fuel cells systems. Journal of Power Technologies. 2013;93:27-36.

[34] Mann RF, Amphlett JC, Hooper MA, Jensen HM, Peppley BA, Roberge PR. Development and application of a generalised steady-state electrochemical model for a PEM fuel cell. Journal of Power Sources. 2000;86(1-2):173-80. 